THE

\title{
JOURNAL OF MENTAL SCIENCE
}

[Published by Authority of the Medico-I'sychological Association of Great Britain and Ireland.]

No. $197\left[\begin{array}{c}\text { NEW sERIss } \\ \text { No. } 161 .\end{array}\right]$ APRIL, I9OI. VOL. XLVII.

\section{D্̉icfoxia, Quteen and Emmpess, \\ Died 22 January, I90I,}

\begin{abstract}
in the Eighty-second Year of her age
\end{abstract}
and the Sixty-fourth Year of her reign.

Through her vast Empire and through the world swept a wave of sorrow, deeper and greater than had ever been known, when the wire flashed the sad tidings. True sorrow filled the hearts of her own People, and true regret and sympathy came from all Nations and Races of men.

It was not only that death had taken the sceptre from the hand of the greatest Ruler in the world, a hand which had wielded it so worthily and so long, but that the Ruler was a true and noble Woman, a very Mother of her people, who drew near to them in all womanly sympathies, all gained their hearts by showing them her own. Nor was the bond one of mutual affection only, for they admired and honoured her wise statesmanship, her constant devotion to duty, her deep interest in all things intellectual, scientific, and philanthropic, which added to human knowledge, human progress, and human wellbeing.

Other lands envied us our Queen. Other Rulers felt her charm and power, and came to share our sorrow when we laid her to rest. Britannia's Queen, as befitted her, sailed to her rest through a lane of great battle-ships, which each in turn saluted the dead Queen as she passed with the deep-tongued reverence of the minute-gun. Not less eloquent was the solemn silence of the countless multitudes who looked with sad eyes and hearts on the mournful pageant in the Metropolis. Not less pathetic was the family procession to Frogmore, with its tender "touch of nature that makes the whole world kin."

She rests from her labours,

And her works do follow her. 